\title{
THE EFFECTS OF READING HABIT TOWARDS STUDENTS' READING COMPREHENSION AT PRIVATE SENIOR HIGH SCHOOLIN PURWAKARTA
}

\author{
Asep Suhana \& Acep Haryudin \\ asepscout9@gmail.com \& haryacep@gmail.com \\ STIB Perdana Mandiri Purwakarta STKIP Siliwangi Bandung
}

\begin{abstract}
The purpose of this research is to find out the effects of reading habit towards student's reading comprehension. The method used is survey method. Samples were 80 students with a simple random technique. The data was collected by distributing questionnaires directly to the sample. Data analysis using descriptive statistics and the research was conducted on March to July 2015. The result showed: 1). There are any significant effects of reading habit towards students' reading comprehension. That is proved by value of $F_{o} 33,221$ and sig $0,000<$ 0,05 . The results of correlation analysis of multiple correlation coefficient obtainedbyRy12=0.681and coefficient determination $=46,3 \%$. While from the regression analysis obtained the regression equation of multiple regression $\left.\widehat{Y}=11.371+0,484 X_{1}+0,393 X_{2} .2\right)$. There is a significant effect of reading habit towards students' reading comprehension. That is proved by the value of $\mathrm{t}_{\text {observe }}=4.926$ and Sig. $0.000<0.05$. 3).
\end{abstract}

Keyword : Reading Habit, Student's Reading Comprehension.

\section{A.INTRODUCTION}

English is one of international language, so that Mastering English is obtained through a variety of teaching programs in schools. Experience showed that the results of learning English at school in Indonesia are still far from desire goals. One of the main problems in learning English in formal education at school today is not learnt well by the students, as if English is still regarded by frightening specter. This accomplishment, of course, teaching learning activity without reading some books does not provide the access for students to develop independently.Harvey (1990:2) argues that purpose of reading in language is to inform ourselves about something we are interested in, or challenge on certain matters.

Reading and academic achievement are essential for research workers and educationists to know that every child whether he or she is gifted, average, normal or backward etc, should be educated in his or her own way but if he or she possesses good study habits, he or she can perform well in academics and in every situation. It is the reading habits which help the learner in obtaining meaningful and desirable knowledge. Good reading habits act as a strong weapon for the students to excel in life (Bashir \& Mattoo, 2012). According to Palani (2012), reading habit is an essential and important aspect for creating a literate society in this world. It shapes the personality of individuals and it helps them to develop proper thinking methods, and creates new ideas. However, the developments in the Mass Media, had continued to influence interest in reading (hard copy of literatures such as...) books, magazines and journals, among others. Based on the explanation above, the researchers finaly conducted the riserch with the entitle "The Effect of Reading Habit towards Students' Reading Comprehension at Private Senior High School at Purwakarta”.

From the background of research above we are able to find some problems that are related to the student's reading comprehension. The writers try to identify the problems into some questions. What is reading comprehension ?Is there any effect of raeding habit towards students' reading comprehension ? Problems have been stated before it can be formulated into questions;Is there any effect of reading habit towards students' reading comprehension?This research hypothesesis:There is a significant effect of reading habit towards students' reading comprehension. The objective of the researchis to know the effect of reading habit towards students' reading comprehension. 


\section{B. LITERATURE REVIEW}

\section{Reading Habit}

\section{a. Definitions of Reading Habit}

Reading habits are well-planned and deliberate pattern of study which has attained a form of consistency on the part of students toward understanding academic subjects and passing at examinations. Reading habits determine the academic achievements of students to a great extent. Both reading and academic achievements are interrelated and dependent on each other. Students often come from different environments and localities with different levels of academic achievement. Therefore, they differ in the pattern of reading habits. While some students have good reading habits, others tend to exhibit poor reading habits. Academic achievement means how much knowledge the individual has acquired from the school (Bashir \& Mattoo, 2012).

Palani (2012) is of the opinion that, effective reading is important avenue of effective learning and reading is interrelated with the total educational process and hence, educational success requires successful reading habit. He believes reading is the identification of the symbols and the association of appropriate meaning with them. It requires identification and comprehension. Comprehension skills help the learner to understand the meaning of words in isolation and in context. Before the advent of the television, both the young and the old found enough time to read. Apart from teachers, other professionals used to spend their leisure time in reading both English and vernacular literature. English medium schools almost always demanded extra reading from their students. But all these have become a thing of the past.

b. Purposes of Reading Habit: From website http://en.wikipedia.org/wiki/habit, reading habit is someone's behavior which does not need much thinking process or repeated activity which is done regularly by him then does continuously as a result it becomes a habit. If reading is a habit, a student would like to get into of course there are a number of ways to cultivate it. The student will realize that reading is highly enjoyable if he or she reads his or her interests. On the other side, if a student has to read a lousy material or an extremely difficult one then he or she is forcing himself through it then it will seem like a chore. If this happens for several times, consider abandoning the material and finding one that he or she likes best. To acquire the habit of reading is to construct you a refuge from almost all the miseries of life.

c. Factors of Reading Habit: Habit cannot come instantly since it needs a long process to be built. Factors influencing habit such as: interests, motivation, and environment. The factors are integrated so that is they cannot be separated. To build a reading habit, for instance, if someone wants to read, he can start reading by choosing interesting and knowledgeable resources such as book, article, newspaper or magazine he/she will try to spend his/her time to read. If this activity is done regularly, automatically, a reading habit can be achieved. Tampubolon (1990:41) confirms that in building the habit we need longer time because the interest and motivation have rule in it. There is no interest and motivation, generally, the habit will never exist. Furthermore, Reid (2007:2) states that habits are our emotional regulators or comforters. Our thinking and behavior follow the grooves in our minds. In this case the researcher states that reading habit is behavior to read which is done regularly to understand information and get entertainment from written material. Reading can be obtain from fiction, nonfiction, book, magazine, newspaper, reading also useful for getting knowledge.

\section{Reading Comprehension}

a. Definitions of Reading Comprehension : Reading is one of the most important activities in human life. By reading, people can get a lot of information and they can also get lots of knowledge that enrich their mind in this globalization era. Reading ability seems to be important acquired by everyone. Logically, it can usually be gained by the process that occurs during the school time or any language classes. Rivers (1981:259) points out that reading is a most important activity in any language class, not only as a source of information and a pleasurable activity, but also as a means of consolidating and extending one's knowledge of the language.

b. The Factors Influencing Reading Comprehension: The factors which influence reading comprehension are divided into two categories namely inside the head and outside the head. According to Johnson and Pearson (1978:9-10), the inside factors will be things like linguistic competence (what the reader knows about the language), interest (how much the reader cares about various topics that might be encountered), motivation (how much the reader cares about the task at hand as well as his or her general mood about reading and schooling) and accumulated reading ability (how well the reader can read). The outside factors fall into two categories, namely the elements on the page and qualities of the reading environment.

c. The Reading Comprehension Skills: There are four kinds of comprehension skills as written by Rubin (1982:107-108), namely literal comprehension, interpretation, critical reading and creative reading. Literal comprehension represents the ability to obtain a low level type of understanding by 
using only information explicitly stated. This category requires a lower level of thinking skills than the other three levels. In other words, this level is considered the lowest level of comprehension.

\section{RESEARCH METHODOLOGY}

\section{Research method}

This study emphasizes on the effects of students' reading habit towards students' reading comprehension. It means there is one independent variable and one dependent variable; variable $\mathrm{X}_{1}$ as the first independent variable (students' reading habit) which has influenced the variable $\mathrm{Y}$ as the dependent variable (students' reading comprehension). The method used is a survey with correlation technique.

2. Place and Time of research: The research is carried out atPrivate Senior High Schoolwhich is located in Subdistrict Purwakarta. This research will be conducted in the odd semester of academic year 2014-2015, precisely from March to July 2015.

3. Population and Sample Selection Technique: Population in this research is all students of public Senior High School in eleventh grade in Purwakarta with 430 students grade Eleven (class XI). The sampling technique used for this survey research is a cluster-simple random sampling - it means taking a sample in cluster, random, and in simple way. It is done because of the wide area and a great deal of population. According to Sugiyono, the cluster-simple random sampling is used in which related to a geographic location of respondents where they are in one school selected randomly as a cluster and regarded that they have an equal position for relevant characteristics towards examined variables. The sample only one schoolis SMA Al Muhajirin Purwakarta. It has about 119 students. The sample are randomly about 80 students in eleventh grade in the even semester for academic 2014-2015 to be samples in this survey research.

4. Technique of data collection: To collect the data, the researchers find out on the field research. The data are namely; Students' Reading Habit, and Comprehension tests for dependent variable. Both questionnaire and objective test are given to 80 students of eleventh class from SMA Muhajirin Purwakarta. Which are set as samples. It can be seen as follow:

Table 1. Data collecting and sourcing

\begin{tabular}{|c|l|c|c|}
\hline No. & \multicolumn{1}{|c|}{ Variables $(\mathbf{X}$, and Y) } & Instrument & Respondent \\
\hline 1 & Students' Reading Habit $(\mathrm{X})$ & Questionnaires & Students \\
\hline 3 & Reading Comprehension $(\mathrm{Y})$ & Formative Test & Students \\
\hline
\end{tabular}

\section{Research Instruments}

\section{Definition Independent Variable: Students' Reading Habit}

a. Conceptual definition: Reading habit behavior to read which is done regularly to understand information and get entertainment from written material. Reading can be obtain from fiction, nonfiction, book, magazine, newspaper, reading also useful for getting knowledge

b. Operational Definition: Reading habit is the total score of the respondents' answers on an instrument of reading habit constructed based on the following indicators: 1). the students want to read for long time and continuously 2). The students prepare the schedule to read all of positive books with the purpose to get the knowledge. 3). The students show the happiness to read. 4). the student can read any kind of book

Since this instrument is kind of perception. So, Likert scale is used to find out about students' preferences by stating; 5 (always), 4 (often), 3 (sometimes), 2 (seldom), and 1 (never).

\section{Definition of Dependent Variable: Reading Comprehension}

a. Conceptual Definition: Reading comprehension is a process of reading involves taking meaning to a text in order to obtain meaning from the text. An individual may be said that he is able to comprehend the text fully when he can recognize the words and sentences of the text, make value judgments and based on the reading experience.

b. Operational Definition: Operationally, reading comprehension is the total score of the respondents' answers of reading comprehension. Objective test constructed by the following indicators; 1). Finding the main idea of a paragraph, 2). Finding written and unwritten information from the text, 3). Finding the detail and factual information, 4). Finding the purpose or moral value of the text, 5). Finding the suitable word for completing the cloze text/passage, 6). Constructing sentence, and 7). Constructing paragraph. The objective test is a sub-set of test with multiple choices given (option A, B, C, or D). It means only one correct answer, while the others are to be the distracters. The correct answer will be graded 1, whereas the incorrect one will be grade 0 . Total items of the instrument are 30 items. It brings consequence that the lowest score will be 0 , while the highest score will be 30 . 


\section{The Result for Instrument's Try Out}

1. Students' Reading Habit

a. Validity Test of Students' Reading Habit

Kind of validity measured in this research is a validity internal consistency by using Pearson product moment. The result gained through the measurement then is compared to $r_{\text {table }}$ of product moment. If the $r_{\text {observed }}$ is bigger than $r_{\text {table, }}$, hence the item of instrument is sentenced valid, or vice versa. The validity data is presented after all the measurement is done completely. For instrument (Students' Reading Habit), since they are all not dichotomy, so the data would be parametric. Thus, the validity test is done by using correlation of product moment, which the formula is presented as follows;

$$
r=\frac{\mathrm{n} \sum \mathrm{XY}-\sum \mathrm{X} \cdot \mathrm{XY}}{\sqrt{n \cdot \sum X^{2}-\left(\sum \cdot X\right)^{2}} \sqrt{n \cdot \sum Y^{2}-\left(\sum Y\right)^{2}}}
$$

Which means:

$$
\begin{array}{ll}
\mathrm{r} & =\text { Coefficient correlation of } \mathrm{X} \text { and } \mathrm{Y} \\
\mathrm{X} & =\text { Total score (for independent variables) } \\
\mathrm{Y} & =\text { Total score (for dependent variables) } \\
\mathrm{N} & =\text { Total respondents }
\end{array}
$$

After conducting the first try out for both instruments to non-sample of 20 people, it is found that several items of instruments are invalid;

1) Instrument of Students' Reading Habit;

\begin{tabular}{|c|c|c|c|}
\hline NO & $\begin{array}{c}\mathbf{r} \\
\text { count }\end{array}$ & $r$ table & Validity result \\
\hline 1 & 0.772 & 0.468 & Valid \\
\hline 2 & 0.706 & 0.468 & Valid \\
\hline 3 & 0.772 & 0.468 & Valid \\
\hline 4 & 0.371 & 0.468 & Drop \\
\hline 5 & 0.772 & 0.468 & Valid \\
\hline 6 & 0.576 & 0.468 & Valid \\
\hline 7 & 0.772 & 0.468 & Valid \\
\hline 8 & 0.116 & 0.468 & Drop \\
\hline 9 & 0.202 & 0.468 & Drop \\
\hline 10 & 0.525 & 0.468 & Valid \\
\hline 11 & 0.652 & 0.468 & Valid \\
\hline 12 & 0.510 & 0.468 & Valid \\
\hline 13 & 0.513 & 0.468 & Valid \\
\hline 14 & 0.642 & 0.468 & Valid \\
\hline 15 & 0.347 & 0.468 & Drop \\
\hline 16 & 0.541 & 0.468 & Valid \\
\hline 17 & 0.628 & 0.468 & Valid \\
\hline 18 & 0.548 & 0.468 & Valid \\
\hline 19 & 0.211 & 0.468 & Drop \\
\hline 20 & 0.604 & 0.468 & Valid \\
\hline 21 & 0.594 & 0.468 & Valid \\
\hline 22 & 0.636 & 0.468 & Valid \\
\hline 23 & 0.637 & 0.468 & Valid \\
\hline 24 & 0.772 & 0.468 & Valid \\
\hline 25 & 0.594 & 0.468 & Valid \\
\hline
\end{tabular}

The total grain instrument of Students' Reading Habit amounted to 25 questions. After testing the 20 respondents, then the validity of the analysis performed, there are grains that has $\mathrm{r}_{\text {observe }}<\mathrm{r}_{\text {table }}(0.468)$, they are number $4,8,9,15$ and 19 . Thus the items are declared invalid and dropped. Table 3.7 shows the result of validity test of instrument of Reading Habit

Table 2. The Validy Test of Instrument of Reading habit

b. Reliability Test of Students' Reading Habit

Total of Validity result $=20$

$$
r_{11}=\left\{\frac{k}{k-1}\right\}\left\{1-\frac{\Sigma s i^{2}}{s t}\right\}
$$




$$
\begin{array}{ll}
\mathrm{K} & =\text { Total of valid items } \\
\sum_{s i} 2 & =\text { Total item variance } \\
\mathrm{St}_{2} & =\text { Total of variance }
\end{array}
$$

If the coefficient of instrument of reliability is bigger than 0.7 , it means that the instrument is fairly reliable. Based on the calculation of reliability for both instruments, it is gained the score of reliability consecutively; 0.901 and 0.905 . since the result is bigger than 0.7 , it means brings consequences that these instruments are reliable and are able to be used as tool of measurement for this research.

\section{Reading Comprehension}

a. Validity Test of Students' Reading Comprehension

Since gained data is dichotomist, so the validity of the reading comprehension instrument is measured by using point bi-serial technique, and the formula is stated as follows;

Where are:

$$
\mathrm{R}_{\mathrm{bis}}=\frac{M_{p} M_{t}}{S D} \times \sqrt{\frac{p}{q}}
$$

$$
\begin{array}{ll}
\mathrm{R}_{\mathrm{bis}} & =\text { Coefficient correlation of point bi-serial } \\
\mathrm{M}_{\mathrm{p}} & =\text { The average score for those who got the correct answer } \\
\mathrm{M}_{\mathrm{t}} & =\text { The average of total score } \\
\mathrm{S}_{\mathrm{t}} & =\text { Standard of deviation of total score } \\
\mathrm{p} & =\text { Level of difficulty } \\
\mathrm{q} & =1-\mathrm{p}
\end{array}
$$

\begin{tabular}{|c|c|c|c|c|c|c|c|c|}
\hline No. Butir & JB & $\mathrm{P}$ & $\mathrm{Q}$ & $\mathrm{Xi}$ & $\mathrm{Xt}$ & $\mathrm{St}$ & r-bis ( Valid ) & Validitas \\
\hline 1 & 16.00 & 0.80 & 0.20 & 19.88 & 19.00 & 7.48 & 0.23 & $\mathrm{R}$ \\
\hline 2 & 9.00 & 0.45 & 0.55 & 24.56 & 19.00 & 7.48 & 0.67 & $\mathrm{~V}$ \\
\hline 3 & 9.00 & 0.45 & 0.55 & 24.56 & 19.00 & 7.48 & 0.67 & V \\
\hline 4 & 14.00 & 0.70 & 0.30 & 22.86 & 19.00 & 7.48 & 0.79 & $\mathrm{~V}$ \\
\hline 5 & 15.00 & 0.75 & 0.25 & 20.73 & 19.00 & 7.48 & 0.40 & $\mathrm{R}$ \\
\hline 6 & 9.00 & 0.45 & 0.55 & 24.56 & 19.00 & 7.48 & 0.67 & V \\
\hline 7 & 14.00 & 0.70 & 0.30 & 22.86 & 19.00 & 7.48 & 0.79 & V \\
\hline 8 & 13.00 & 0.65 & 0.35 & 23.15 & 19.00 & 7.48 & 0.76 & $\mathrm{~V}$ \\
\hline 9 & 18.00 & 0.90 & 0.10 & 18.28 & 19.00 & 7.48 & -0.29 & $\mathrm{R}$ \\
\hline 10 & 13.00 & 0.65 & 0.35 & 23.15 & 19.00 & 7.48 & 0.76 & $\mathrm{~V}$ \\
\hline 11 & 13.00 & 0.65 & 0.35 & 23.15 & 19.00 & 7.48 & 0.76 & $\mathrm{~V}$ \\
\hline 12 & 19.00 & 0.95 & 0.05 & 19.05 & 19.00 & 7.48 & 0.03 & $\mathrm{R}$ \\
\hline 13 & 11.00 & 0.55 & 0.45 & 20.00 & 19.00 & 7.48 & 0.15 & $\mathrm{R}$ \\
\hline 14 & 13.00 & 0.65 & 0.35 & 23.15 & 19.00 & 7.48 & 0.76 & $\mathrm{~V}$ \\
\hline 15 & 11.00 & 0.55 & 0.45 & 22.82 & 19.00 & 7.48 & 0.56 & V \\
\hline 16 & 14.00 & 0.70 & 0.30 & 21.93 & 19.00 & 7.48 & 0.60 & $\mathrm{~V}$ \\
\hline 17 & 8.00 & 0.40 & 0.60 & 23.50 & 19.00 & 7.48 & 0.49 & $\mathrm{~V}$ \\
\hline 18 & 11.00 & 0.55 & 0.45 & 24.27 & 19.00 & 7.48 & 0.78 & $\mathrm{~V}$ \\
\hline 19 & 19.00 & 0.95 & 0.05 & 19.68 & 19.00 & 7.48 & 0.40 & $\mathrm{R}$ \\
\hline 20 & 12.00 & 0.60 & 0.40 & 20.33 & 19.00 & 7.48 & 0.22 & $\mathrm{R}$ \\
\hline 21 & 9.00 & 0.45 & 0.55 & 24.33 & 19.00 & 7.48 & 0.64 & V \\
\hline 22 & 18.00 & 0.90 & 0.10 & 18.89 & 19.00 & 7.48 & -0.04 & $\mathrm{R}$ \\
\hline 23 & 13.00 & 0.65 & 0.35 & 23.15 & 19.00 & 7.48 & 0.76 & $\mathrm{~V}$ \\
\hline 24 & 9.00 & 0.45 & 0.55 & 24.33 & 19.00 & 7.48 & 0.64 & V \\
\hline 25 & 13.00 & 0.65 & 0.35 & 23.15 & 19.00 & 7.48 & 0.76 & $\mathrm{~V}$ \\
\hline 26 & 7.00 & 0.35 & 0.65 & 24.00 & 19.00 & 7.48 & 0.49 & $\mathrm{~V}$ \\
\hline 27 & 13.00 & 0.65 & 0.35 & 18.62 & 19.00 & 7.48 & -0.07 & $\mathrm{R}$ \\
\hline 28 & 14.00 & 0.70 & 0.30 & 21.93 & 19.00 & 7.48 & 0.60 & $\mathrm{~V}$ \\
\hline 29 & 15.00 & 0.75 & 0.25 & 21.40 & 19.00 & 7.48 & 0.56 & $\mathrm{~V}$ \\
\hline 30 & 8.00 & 0.40 & 0.60 & 23.50 & 19.00 & 7.48 & 0.49 & $\mathrm{~V}$ \\
\hline & & & & & \multicolumn{4}{|c|}{ Total of Validity result $=21$} \\
\hline
\end{tabular}

After conducting the first try out for this instrument to non-sample of 20 people, it is found that 9 items of instruments are invalid. They are number 1,5,9,12,13,19,20,22 and 27. To make instrument valid, all the invalid items are revised and replaced by another items and re-tried out, until all the items are sentenced valid. Therefore, this instrument can be used as a tool of measurement for this research.

Table 3: The Validy Test of Instrument of Reading Comprehension 


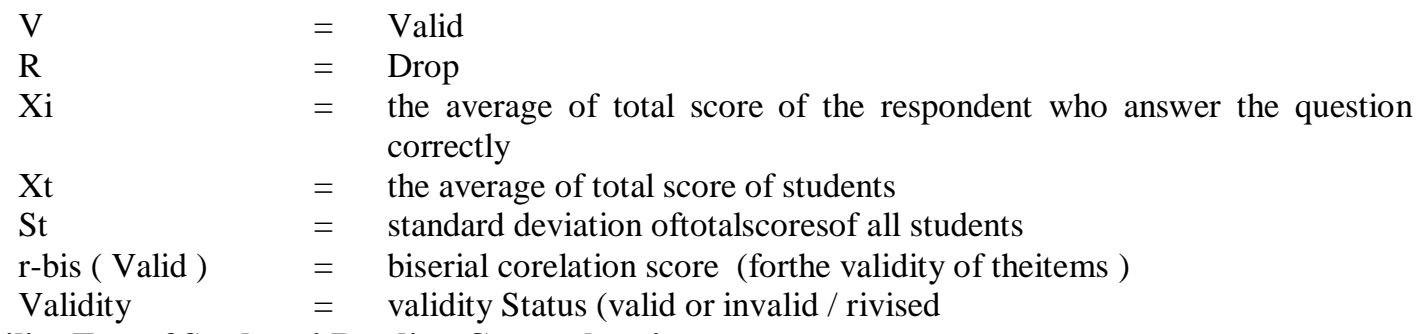

\section{b. Reliability Test of Students' Reading Comprehension}

The reliability test for reading comprehension instrument is gained through computation by using spearman-brown, which the formula is stated as follows;

$$
r=\frac{2 r_{12}}{\left(1+r_{12}\right)}
$$

Reliability test for the instrument of learning achievement variable using the Kuder Richardson formula, i.e when the score $r_{i i}$ is getting closer to the perfect score 1 , then the instrument is more reliable, whereas if the score $r_{i i}$ is getting closer to score 0 , then the instrument is less reliable. The result of the reliability obtained $r_{i i}=$ 0.984 , thus it can be stated that instrument of learning achievementis reliable.

\section{Techniques of Data Analysis}

\section{Descriptive Analysis}

The descriptive analysis is done by presenting the data in the form of frequency distribution table, polygon graphic, and also histogram for each research variable. Furthermore, for each group of data will be processed and analyzed about the size of; mean, median, mode, standard deviation, skewness and also kurtosis. For the descriptive data processing, the tabulation is performed by SPSS 20.0 for windows, with the manual formula presented as follows:

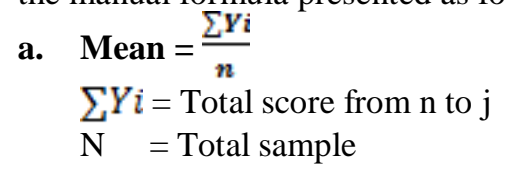

b. $\quad$ Mode $=\mathbf{b}+\mathbf{p}\left(\frac{b_{1}}{b_{1+b_{1}}}\right)$

$\mathrm{b}=$ The border of interval class and the most frequency

$\mathrm{p}=$ The swap of interval class

$\mathrm{b}_{1}=$ Frequency of mode class - frequency of previous interval class

$\mathrm{b}_{2}=$ Frequency of mode class - frequency of upcoming interval class

c. $\quad$ Median $=\mathbf{b}+\mathbf{p}\left[\frac{\frac{1}{2^{n-F}}}{f}\right]$

$\mathrm{b}=$ The under limit, where the median lies

$\mathrm{n}=$ Total data or sample

$\mathrm{F}=$ Total of all frequencies before median class

$\mathrm{f}=$ Frequency of medium class

d. Standard deviation $=\frac{\sqrt{\sum Y^{2}-\frac{\left(\Sigma V^{2}\right.}{n}}}{n_{1}}$

$\Sigma \mathrm{Y}=$ total score from $\mathrm{n}$ to $\mathrm{j}$

$\mathrm{n}=$ total sample

\section{Prerequisite test for data analysis}

The prerequisite test are done to find out whether the collected data is worthy enough to be analyzed later on by using statistical tool. The prerequisite tests are normally test and linearity test. For the research, the prerequisite tests are performed by using SPSS 20.0 version for window.

\section{a. Normality test}

The normality test is done by using Lilliefors test with criteria if the score of $\mathrm{L}_{\text {observed }}<\mathrm{L}_{\text {table, }}$, it means that the data comes from normal population, or vice versa. The score of $\mathrm{L}_{\text {observed }}$ is gained through calculation by using manual formula as stated in following:

$\mathrm{Yi}=$ data from each samples

$$
\mathrm{Zi}=\frac{Y i-\hat{Y}}{S i}
$$

$\mathrm{Y}=$ the average

$\mathrm{Si}=$ standard deviation 
The score of $\mathrm{F}(\mathrm{Zi})$ is gained by following the rule of rigid normal distribution which then is also counted the score of probability for $\mathrm{F}(\mathrm{Zi})=\mathrm{P}(\mathrm{Z}<\mathrm{Zi})$. The score of $\mathrm{L}_{\text {observed }}$ is gained from the biggest score as the result of subtraction between $\mathrm{F}(\mathrm{Zi})$ and $\mathrm{S}(\mathrm{Zi})$. While the score of $\mathrm{L}_{\text {table }}$ is gained from the table of Lilliefors.

\section{b. Linearity test}

The test of linearity for regression line for this research is done by using F test (Sudjana, 1996: 327), which the formula is stated as follow:

Where are:

$$
\mathrm{F}=\frac{s_{P C}^{2}}{s_{E}^{2}}=\frac{\frac{U \kappa_{P C}}{k-2}}{\frac{j(\mathbb{k})}{n-k}}
$$

$\mathrm{JK}_{\mathrm{TC}}=\mathrm{JK}_{\mathrm{res}}-\mathrm{JK}_{\mathrm{E}}$, is called the sum of mismatch squares

$\mathrm{JK}_{\mathrm{E}}=\Sigma\left\{\sum_{i} y i^{2}-\frac{\left(y^{2}\right)^{2}}{n}\right\}$ is called the sum of fallacy squares, while $\mathrm{K}$ is

regrouping for data $\mathrm{X}$.

$\mathrm{JK}(\mathrm{b} / \mathrm{a})=\mathrm{b} \sum \mathrm{xi}, \mathrm{yi}-\frac{\sum x i \sum y i}{n}$ is called the sum of regression squares $(\mathrm{b} / \mathrm{a}), \mathrm{JK}(\mathrm{a})=\frac{\left(\sum y i\right)}{n}$, is called also sum of the regression squares (a).

The score of $F_{\text {observed }}$ is then compared to the score of $F_{\text {table }}$ with $\alpha=5 \%$. The criteria for linearity test is if $F_{\text {obseved }}>F_{\text {table, }}$, it means that the regression line is linear.

3.

The Test of Research Hypothesis (Inferential Analysis)

After all data analysis requirement test was met and found out that the data is feasible to be further processed, so the next step is to test each proposed hypothesis. Hypothesis test using partial correlation technique, multiple correlation, a simple linear regression and a correlation test both partial and multiple. These will use SPSS 20.0 program. The criteria of the test are as follows:

a. Correlation Analysis

1) The calculation and test of Significance Partial Correlation Coefficient.

The result of calculation partial correlation coefficient can be seen from the output of SPSS program through correlation analysis namely, in significance table from the correlation table from the correlation coefficient stated by the remark of the table below:

- $\quad$ For ** (two stars) means the correlation coefficient is significant in a real standard of $1 \%$

- $\quad$ For * (one star) means the correlation coefficient is significant in a real standard of 5\%, means it is not significant in a real standard $1 \%$.

- $\quad$ For those which do not have a sign means the correlation coefficient is not significant.

2) The Calculation and the Test of Significance Double Correlation Coefficient.

The result of double correlation coefficient can be seen from the output SPSS program through the regression analysis in the model

Summary. The significance of correlation coefficient was tested manually or the computer aid the application of Microsoft Excel. The formula of the test is:

Where :

$$
F=\frac{\frac{R^{2}}{k}}{\frac{1-R^{2}}{n-k-1}}
$$

$\mathrm{R}=$ Ry.12 i.e. Double Correlation Coefficient

$\mathrm{N}=$ The amount of sample

$\mathrm{K}=$ The amount of independent variables

b. The Regression Analysis

1) The calculation of Regression Line Equation

The result of regression line calculation can be seen from the output SPSS program through the regression analysis namely; Coefficient ${ }^{\mathbf{a}}$ table. The coefficient, regression line equation was shown in by the number in B column for unstandardized Coefficients.

2) The test of Regression Significance

a. For the Partial Regression

For the partial regression significance test was carried out by paying attention to the score in $\mathrm{t}$ column or Sig. column in the coefficients table. For the partial regression, the effect of X1 variable, while for the partial regression, the effects of X2 towards $\mathrm{Y}$ using the score $\mathrm{t}$ and Sig. in row $\mathrm{X} 2$ variable.

- If using Sig.column, so the significance criteria is:

"If Sig. < 0,05 so the regression is significant" 
- If using $t$ column, so the significance criteria is:

"If tobserved $>$ table so the regression is significant"

$\boldsymbol{F} \boldsymbol{t}_{\text {table }}$ is chosen based on the statistical test rule in the t distribution namely; a real standard $\alpha$ and $\mathrm{dk}=\mathrm{n}-2$, where $\mathrm{n}$ is the number of samples.

b.For the Double Regression

The result of the double regression test can be seen from the output of SPSS program through the

8. Statistics hypothesis

regression analysis namely; in the table of $\mathbf{A N O V A}^{\mathbf{b}} \mathbf{F}$ column or Sig.

The hypotheses for this research are stated as follow:

1) Hypothesis 2

$\mathrm{H} 0: \beta=0$ there is no effect of Students' Reading Habit towards students' reading

$\mathrm{H} 1: \beta \neq 0$ comprehension

there is an effect of Students' Reading Habit towards students' reading comprehension

\section{RESEARCH FINDING AND DISCUSSION}

\section{A. Description of Data}

\section{Students' Reading Comprehension ( $Y$ )}

The variable of students' reading comprehension is scores obtained based on students' understanding to a text. To measure Students' reading comprehensionthe researchersposed the research instrument consist of 21 multiple choice item questions. Out of 80 respondents, it is known that the scores are in the range 38 to 98. Meaning that the minimum score is 38 and the maximum score is 98 . In addition, mean (average of all scores in the data set) is 80.46 , median (score at centre of distribution) is 80.00 and mode (most frequently score in the data set) is 80 and for standard deviation is 9,390. The whole data can be clearly seen in the following table:

Table 4.Data Description of Students' reading comprehension

\begin{tabular}{|c|c|c|}
\hline \multicolumn{3}{|c|}{ Statistics } \\
\hline \multicolumn{3}{|c|}{ Students' Reading Comprehension } \\
\hline \multirow[t]{2}{*}{$\mathrm{N}$} & Valid & 80 \\
\hline & $\begin{array}{l}\text { Missin } \\
\mathrm{g}\end{array}$ & 0 \\
\hline \multicolumn{2}{|c|}{ Mean } & 80.46 \\
\hline \multicolumn{2}{|c|}{ Median } & 80.00 \\
\hline \multicolumn{2}{|c|}{ Mode } & 80 \\
\hline \multicolumn{2}{|c|}{ Std. Deviation } & 9.390 \\
\hline \multicolumn{2}{|c|}{ Range } & 38 \\
\hline \multicolumn{2}{|c|}{ Minimum } & 60 \\
\hline \multicolumn{2}{|c|}{ Maximum } & 98 \\
\hline
\end{tabular}

From the data analysis result above, it can be said that reading comprehension on students class XI in Private senior high school in Purwakarta are good, it can be seen with the average score is 80.46 nearly to median score 80,00, and also from the table above we can make frequency distribution and histogram for the variable of students' reading of English which is usefull for completing data research as the following table :

Table 5. Frequency Distribution of Students' reading of English

\begin{tabular}{|c|c|r|r|r|r|}
\hline \multicolumn{7}{|c|}{ Students' Reading Comprehension } \\
\hline \multirow{2}{*}{$\begin{array}{c}\text { Vali } \\
\text { d }\end{array}$} & Frequency & $\begin{array}{c}\text { Percen } \\
\text { t }\end{array}$ & $\begin{array}{c}\text { Valid } \\
\text { Percent }\end{array}$ & $\begin{array}{c}\text { Cumulative } \\
\text { Percent }\end{array}$ \\
\cline { 2 - 6 } & 60 & 4 & 5.0 & 5.0 & 5.0 \\
\cline { 2 - 6 } & 63 & 1 & 1.3 & 1.3 & 6.3 \\
\cline { 2 - 6 } & 64 & 1 & 1.3 & 1.3 & 7.5 \\
\cline { 2 - 6 } & 66 & 1 & 1.3 & 1.3 & 8.8 \\
\cline { 2 - 6 } & 68 & 2 & 2.5 & 2.5 & 11.3 \\
\cline { 2 - 6 } & 70 & 5 & 6.3 & 6.3 & 17.5 \\
\cline { 2 - 6 } & 73 & 4 & 5.0 & 5.0 & 22.5 \\
\cline { 2 - 6 } & 75 & 2 & 2.5 & 2.5 & 25.0 \\
\cline { 2 - 6 } & 76 & 5 & 6.3 & 6.3 & 31.3 \\
\cline { 2 - 6 } & 78 & 5 & 6.3 & 6.3 & 37.5 \\
\cline { 2 - 6 } & 80 & 16 & 20.0 & 20.0 & 57.5 \\
\hline
\end{tabular}




\begin{tabular}{|c|c|r|r|r|r|}
\hline & 83 & 6 & 7.5 & 7.5 & 65.0 \\
\cline { 2 - 5 } & 85 & 4 & 5.0 & 5.0 & 70.0 \\
\cline { 2 - 5 } & 86 & 1 & 1.3 & 1.3 & 71.3 \\
\cline { 2 - 6 } & 87 & 6 & 7.5 & 7.5 & 78.8 \\
\hline & 88 & 4 & 5.0 & 5.0 & 83.8 \\
\hline & 92 & 3 & 3.8 & 3.8 & 87.5 \\
\hline & 93 & 2 & 2.5 & 2.5 & 90.0 \\
\hline & 95 & 6 & 7.5 & 7.5 & 97.5 \\
\hline & 98 & 2 & 2.5 & 2.5 & 100.0 \\
\hline & $\begin{array}{l}\text { Tot } \\
\text { al }\end{array}$ & 80 & 100.0 & 100.0 & \\
\hline
\end{tabular}

Figure 1. Polygon HistogramDistribution of Data of Students' reading of English

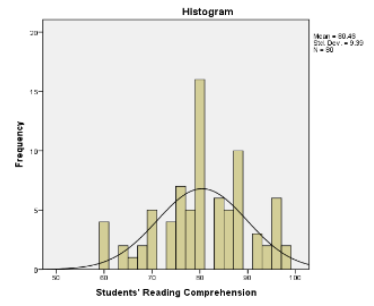

From the analysis ofdataforvariable of the Students' reading comprehension, the diversity ofthe data isindicated by thescore standard of deviation 9,390. Datafromthisvariablehas 80.46 for mean,80 for modeand80,00 for median.Furthermore, from the table of the frequency of distribution is known that $42,5 \%$ of studentshas students' reading comprehensionover theaverage, $20 \%$ of students is atan average andstudents with students' reading comprehensionbelow theaverage is 37,5 \%.Based on Frequencyand Polygon Histogram distributions above concluded that the data of reading comprehension on student in class XI Private senior high school in Purwakarta have a normal spreading.

\section{Students' reading habit $(X)$}

Data of Students' reading habittaken from a questionnaire. Each questionnaire consists of 20 items. Out of 80 respondents, it is known that the scores are in the range 37 to 97 . Meaning that the minimum score is 37 and the maximum score is 97 . In addition, mean (average of all scores in the data set) is 81.86, median (score at centre of distribution) is 83.00 , mode (most frequently score in the data set) is 86 and for standard deviation is 8,811 . The whole data can be clearly seen in the following table:

Table 6. Data Description of Students' Reading Habit

\begin{tabular}{|c|c|c|}
\hline \multicolumn{3}{|c|}{ Statistics } \\
\hline \multicolumn{3}{|c|}{ Students' Reading Habit } \\
\hline \multirow[t]{2}{*}{$\mathrm{N}$} & Valid & 80 \\
\hline & $\begin{array}{l}\text { Missin } \\
\mathrm{g}\end{array}$ & 0 \\
\hline \multicolumn{2}{|c|}{ Mean } & 81.86 \\
\hline \multicolumn{2}{|c|}{ Median } & 83.00 \\
\hline \multicolumn{2}{|c|}{ Mode } & 86 \\
\hline \multicolumn{2}{|c|}{ Std. Deviation } & 8.811 \\
\hline \multicolumn{2}{|c|}{ Range } & 37 \\
\hline \multicolumn{2}{|c|}{ Minimum } & 60 \\
\hline \multicolumn{2}{|c|}{ Maximum } & 97 \\
\hline
\end{tabular}

From the data analysis result above, it can be said that reading comprehension on students class XI in Private senior high school in Purwakarta are good, it can be seen with the average score is 81.86 nearly to median score 83.00.Then fromthe abovetable, it can bemadefrequency of distributionandhistogram for the variable of students' reading habitat class XI in senior high school in Purwakarta which is usefultocomplementthe presentation ofdataas shown below:

Table 7. Frequency Distribution of Students' Reading Habit

\begin{tabular}{|l|c|r|r|r|r|}
\hline \multicolumn{7}{|c|}{ Students' Reading Habit } \\
\hline \multicolumn{2}{|c|}{} & $\begin{array}{c}\text { Frequenc } \\
\text { y }\end{array}$ & Percent & $\begin{array}{c}\text { Valid } \\
\text { Percent }\end{array}$ & $\begin{array}{c}\text { Cumulative } \\
\text { Percent }\end{array}$ \\
\hline \multirow{2}{*}{$\begin{array}{l}\text { Vali } \\
\text { d }\end{array}$} & 60 & 1 & 1.3 & 1.3 & 1.3 \\
\cline { 2 - 7 } & 63 & 1 & 1.3 & 1.3 & 3.8 \\
\cline { 2 - 7 } & 65 & 1 & 1.3 & 1.3 & \\
\hline
\end{tabular}




\begin{tabular}{|l|r|r|r|r|r|}
\hline 67 & 4 & 5.0 & 5.0 & 8.8 \\
\hline 70 & 4 & 5.0 & 5.0 & 13.8 \\
\cline { 2 - 6 } & 72 & 2 & 2.5 & 2.5 & 16.3 \\
\hline 74 & 2 & 2.5 & 2.5 & 18.8 \\
\hline 76 & 7 & 8.8 & 8.8 & 27.5 \\
\hline 77 & 3 & 3.8 & 3.8 & 31.3 \\
\hline 78 & 7 & 8.8 & 8.8 & 40.0 \\
\hline 80 & 5 & 6.3 & 6.3 & 46.3 \\
\hline 83 & 6 & 7.5 & 7.5 & 53.8 \\
\hline 85 & 7 & 8.8 & 8.8 & 62.5 \\
\hline 86 & 9 & 11.3 & 11.3 & 73.8 \\
\hline 88 & 2 & 2.5 & 2.5 & 76.3 \\
\hline 90 & 4 & 5.0 & 5.0 & 91.3 \\
\hline & 7 & 8.8 & 8.8 & 92.5 \\
\hline 92 & 2 & 2.5 & 2.5 & 95.0 \\
\hline 94 & 2 & 2.5 & 2.5 & 100.3 \\
\hline 95 & 1 & 1.3 & 1.3 & \\
\hline
\end{tabular}

Then fromthe abovetable,it can bemadehistogram for the variable of reading habit

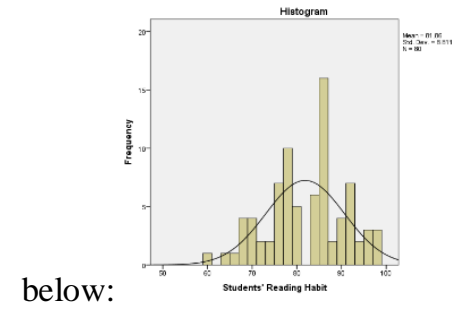

Figure 2. Polygon Histogramfor Distribution Data of Students' Reading Habit

From the analysis ofdataforvariable of the Students' reading comprehension, the diversity ofthe data isindicated by thescore standard of deviation 8.811Datafromthisvariablehas 81.86for mean,86 for modeand83.00for median.Furthermore, from the table of the frequency of distribution is known that 46,2 \% of studentshas Students' reading comprehensionover theaverage 7,5\% of students is atan average andstudents with Students' reading comprehensionbelow theaverage is $46,3 \%$.

Based on Frequency and Polygon Histogram distributions above concluded that the data of reading comprehension on student in class XI Private senior high school in Purwakarta have a normal spreading.

Table 8. SummaryDescription ofData of VariableY, and $X$

\begin{tabular}{|l|l|c|c|}
\hline \multicolumn{2}{|c|}{} & \multicolumn{2}{|c|}{$\begin{array}{c}\text { Studistics } \\
\text { Ctudent's Reading }\end{array}$} \\
\hline \multirow{2}{*}{$\mathrm{N}$} & Valid & 80 & $\begin{array}{c}\text { Student's Reading } \\
\text { Habit }\end{array}$ \\
\cline { 2 - 4 } & Missing & 0 & 80 \\
\hline Mean & 80.46 & 0 \\
\hline Median & 80.00 & 81.86 \\
\hline Mode & 80 & 83.00 \\
\hline Std. Deviation & 9.390 & 86 \\
\hline Range & 38 & 8.811 \\
\hline Minimum & 60 & 37 \\
\hline Maximum & 98 & 60 \\
\hline
\end{tabular}

B. The Test of Requirements Analysis

The test of requirements of the data analysis in this study is testing normality, homogeneity, and linearity of line regression between free variables and bound variable.

1. Assumption Classic Test

\section{a. The Test of Data Normality}


The Regression requirement is called good if the result of the research was following the normal distribution. The test of the normality of the data of each sample was tested through the following hypothesis:

$\mathrm{H}_{0}$ : Data of sample is normally distributed

$\mathrm{H}_{1}$ : Data of sample is not normally distributed

The calculation is done with the help of a computer through an application program SPSS 20.0. According to the conditions in the program, the criteria of normality of the data is "if the $p$ value (sig) $>0.05$ then $\mathrm{H}_{0}$ isaccepted ", which means the data on this sample are normally distributed. The $p$ value (sig) is the number listed on the sig column in the results table / output of calculation of normality testing by SPSS 20.0 program. In this case the method used Kolmogorov-Smirnov. The results of calculations can be seen in Table 4.8

Table 9. Test of Data Normality

\begin{tabular}{|c|c|c|c|}
\hline \multicolumn{4}{|c|}{ One-Sample Kolmogorov-Smirnov Test } \\
\hline & & $\begin{array}{l}\text { Student's Reading } \\
\text { Comprehension }\end{array}$ & $\begin{array}{c}\text { Student's Reading } \\
\text { Habit }\end{array}$ \\
\hline \multicolumn{2}{|l|}{$\mathrm{N}$} & 80 & 80 \\
\hline \multirow[t]{2}{*}{ Normal Parameters ${ }^{\mathrm{a}, \mathrm{b}}$} & Mean & 80.46 & 81.86 \\
\hline & $\begin{array}{l}\text { Std. } \\
\text { Deviation }\end{array}$ & 9.390 & 8.811 \\
\hline \multirow{3}{*}{$\begin{array}{l}\text { Most Extreme } \\
\text { Differences }\end{array}$} & Absolute & .105 & .102 \\
\hline & Positive & .095 & .069 \\
\hline & Negative & -.105 & -.102 \\
\hline \multicolumn{2}{|l|}{ Kolmogorov-Smirnov Z } & .942 & .909 \\
\hline \multicolumn{2}{|l|}{ Asymp. Sig. (2-tailed) } & .337 & .381 \\
\hline \multicolumn{4}{|c|}{ a. Test distribution is Normal. } \\
\hline \multicolumn{4}{|c|}{ b. Calculated from data. } \\
\hline
\end{tabular}

Based on the table above, it was indicated that hypothesis test for data distribution to this regression analysis has followed normality distribution. It can be shown with whole scores Asymp. Sig > 0,05. It was mean that every data have normally distribution. in other wordsthat sample datafromthe freevariablesand the boundvariablesin this studyare normally distributed.

\section{b. Heteroscedasticities Test}

Heteroscedasticities means if the error or residual variance that observed does not have a constant.

Heteroscedasticity condition often occurs in the cross section data, or data taken from some respondents at a certain time.

One of methods for detecting the presence of heteroscedasticity is to make the Scatter-Plot between Standardized Residual (ZRESID) and Standardized Predicted Value (Y caps). In the picture below showed no change $e$ along the Y hat, and then stated that there is no heteroscedasticity in errors (error / residual).

Tostrengthentheresults of the research is shown Histogram Frequency, Normal P-P Plot of Regression Standardized Residual and Scatterplot heteroscedasticities test for dependent variable: Students' reading comprehension

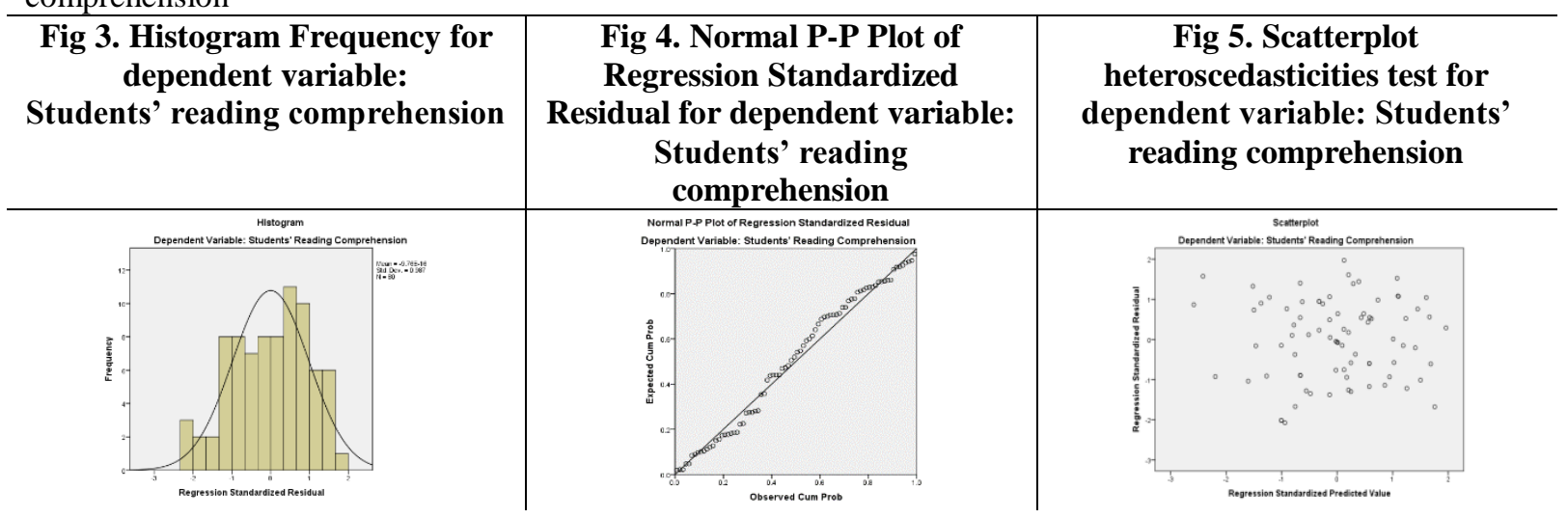

From the figure above shown that the points spread randomly and did not form for a specific pattern clearly, as well as the spreading above is underneath the number 0 on axis $\mathrm{Y}$. In this case indicated that there is no heteroscedasticity in that regression model, so it can be used to predict variable students' reading comprehension based on students' reading habit and learning motivation.

\section{c. Error Normality Test}

The requirements regression called good if the research data follow a normal distribution. 
Table 10.Error Normality Test

\begin{tabular}{|c|c|c|}
\hline \multicolumn{3}{|c|}{ One-Sample Kolmogorov-Smirnov Test } \\
\hline & & $\begin{array}{l}\text { Unstandardized } \\
\text { Residual }\end{array}$ \\
\hline \multicolumn{2}{|l|}{$\mathrm{N}$} & 80 \\
\hline \multirow[t]{2}{*}{ Normal Parameters ${ }^{\mathrm{a}, \mathrm{b}}$} & Mean & $0 \mathrm{E}-7$ \\
\hline & $\begin{array}{l}\text { Std. } \\
\text { Deviation }\end{array}$ & 6.87991650 \\
\hline \multirow{3}{*}{$\begin{array}{l}\text { Most Extreme } \\
\text { Differences }\end{array}$} & Absolute & .090 \\
\hline & Positive & .079 \\
\hline & Negative & -.090 \\
\hline \multicolumn{2}{|l|}{ Kolmogorov-Smirnov Z } & .801 \\
\hline \multicolumn{2}{|c|}{ Asymp. Sig. (2-tailed) } & .542 \\
\hline \multicolumn{3}{|c|}{ a. Test distribution is Normal. } \\
\hline \multicolumn{3}{|c|}{ b. Calculated from data. } \\
\hline
\end{tabular}

The above table shown that the hypothesis test in explaining the distribution of residuals in the regression analysis is to follow the normal distribution. This is indicated by the value of $\mathrm{Z}=0.801$ and $\mathrm{Sig}$. $=0.542>0.05$. This means that assumptions or regression analysis requirements are met.

\section{Linarites Test}

Linearity test performed to determine whether the regression analysis techniques in the independent variables $(\mathrm{X})$ and the dependent variable $(\mathrm{Y})$ is formed linear. This linearity test is used SPSS 20.0 calculation.

\section{a. Regression Linearity Test Affect Variable Xon Y}

The results of regression linearity test between students perception on students' reading habit with students' reading comprehension, the calculation by using SPSS 20.0 as follows:

Table 11. The Results of Regression Linearity Test Variable Xon Y

\begin{tabular}{|c|c|c|c|c|c|c|c|}
\hline \multicolumn{8}{|c|}{ ANOVA Table } \\
\hline & & & $\begin{array}{c}\text { Sum of } \\
\text { Squares }\end{array}$ & df & Mean Square & $\mathrm{F}$ & Sig. \\
\hline \multirow{5}{*}{$\begin{array}{l}\text { Students' Reading } \\
\text { Comprehension * } \\
\text { Students' Reading } \\
\text { Habit }\end{array}$} & \multirow{3}{*}{$\begin{array}{l}\text { Between } \\
\text { Groups }\end{array}$} & (Combined) & 3191.159 & 20 & 159.558 & 2.494 & .003 \\
\hline & & Linearity & 2523.368 & 1 & 2523.368 & 39.441 & .000 \\
\hline & & $\begin{array}{l}\text { Deviation } \\
\text { from } \\
\text { Linearity }\end{array}$ & 667.791 & 19 & 35.147 & .549 & .926 \\
\hline & \multicolumn{2}{|c|}{ Within Groups } & 3774.729 & 59 & 63.978 & & \\
\hline & \multicolumn{2}{|c|}{ Total } & 6965.887 & 79 & & & \\
\hline
\end{tabular}

Based on the calculation above, results obtained Deviation from Linearity with Fo $=0.549$ and Sig. $=0.926>0.05$. This has meaning that the variable students' reading habit with the students' reading comprehension teachers has a linear relationship.

C. The Testing of Hypothesis

1. The effect of Students' reading habit $(\mathrm{X})$ towards Students' reading comprehension $(\mathrm{Y})$. Hypotheses were tested:

$$
\begin{aligned}
& H_{0}: \beta_{y 1}=0 \\
& H_{1}: \beta_{y 1} \neq 0 \\
& \text { Means: }
\end{aligned}
$$

$\mathrm{H}_{0}$ : There is no effect of students' reading habit altogether towards the students' reading comprehension

$\mathrm{H}_{1} \quad$ : There is an effect of students' reading habit altogether towards the students' reading comprehension

From the table 4.15 above, it can be stated that there is a significant effect of students' reading habit towards students' reading comprehension. This is evidenced by the acquisition value of $\mathrm{t}_{\text {observe }}=$ 4.926 and Sig. $0.000<0.05$.

The contribution of the variable students' reading habit towards Students' reading comprehension can be expressed by the formula: 
$\mathrm{KD}=$ Value $\beta_{x 1 y} \times$ value partial correlation $\left(r_{x 1 y}\right) \times 100 \%$

$\mathrm{KD}=0,454 \times 0,602 \times 100 \%=27.33 \%$

From the calculation above, it can be stated that the contribution of the students' reading habit to improving students' reading comprehension about $27.33 \%$

\section{E. CONCLUSION}

So, according to the results above, it can be concluded that students' perception on the students' reading habit has a positive influence in improving students' reading comprehension in students class XI Private senior high school in Purwakarta. This case implied that the students' reading habit gave significant influence on the improvement of students' reading comprehension in students of class XI Private senior high school in Purwakarta. Reading habits are well-planned and deliberate pattern of study which has attained a form of consistency on the part of students toward understanding academic subjects and passing at examinations.

From quantitative information and theories that the researchers concluded that there is influence of students' reading habit towards students' reading comprehension. and finally based on the results of hypotheses testing and data analysis, can be conclude that there is a significant effect of reading habit towards student's reading comprehension. That is proved by the value of $\mathrm{t}_{\text {observe }}=4.926$ and Sig. $0.000<0.05$.

\section{F.REFERENCES}

Arikunto, Suharsimi. 2006. Prosedur Penelitian: Suatu pendekatan Praktik. Edisi Revisi VI. Jakarta: Rineka Cipta.

Brown, H.D.2004. Language Assessment: Principles and Classroom Practices. New York. Longman.

Balitbang SMK Negri 1 Samarinda, Hubungan Prestasi Dengan Minat, 2003, http://guruvalah.com

D.P., Tampubolon. 1990. Kemampuan Membaca. Bandung: Angkasa.

Fraenkel, Jack R and Norman. 2003. How to Design and Evaluate Research in Education. McGraw-Hill.

Goodman, Yetta M and Burke, Carolyn. 1980. Reading Stategies: Focus onComprehension. USA: Holt, Rinehart and Winston.

Grabe, William and Stoller, Fredricka L. 2002. Teaching and Researching Reading. Longman. Pearson Education.

Grellete, Frangoise. 1981. Developing Reading Skill. A Practical Guide to Reading Comprehension Exercises. Cambridge: Cambridge University Press.

Harmer, Jeremy. 2002. How to Teach Vocabulary. England: Longman.

Harris, Albert J and Sipay, Edward R. 1975. How to Increase Reading Ability. Sixth Edition. New York: David Mckay Company, Inc.

Hasibuan, H. Malayu SP, Organisasi dan motivasi dasar peningkatan produktifitas, ( Jakarta : Bumi aksara, 1996)

Hornby, A.S. 1995.Oxford Advanced Learner's Dictionary. New York: Oxford University Press.

Johnson, D.D. and Pearson, P.D. 1978. Teaching Reading Comprehension. New York: Holt.

Kathrerine, Harber and Pyton, Geofrey. 1989. Heinemann English Dictionary. New Edition. Oxford: Heinemann Educational.

Lado, Robert. 1964.Language Teaching: A Scientific Approach. USA: McGraw-Hill, Inc.

Lye, John. 2007. Something Called Habit. Cambridge: Cambridge University Press.

Nasr, Raja T. 1972. Teaching and Learning English: Selected and SimplifiedReadings. London: Longman.

Notion, Paul. 1990. Teaching and Learning Vocabulary. Boston: Heinle \& Heince Publisher.

Nurgiantoro, dkk. 2009. Statistika Terapan untuk Penelitian Ilmu-Ilmu Sosial. Yogyakarta: Gadjah Mada University Press.

Nuttall, Christine. 1996. Teaching Reading Skills: In a Foreign Language.Heinemann.

Reid, Elizabeth. 2002. What's your habit?. Wellington: University of Wellington.

Richard, Denny, Sukses Memotivasi Jurus-Jurus Meningkatkan Prestasi, (Jakarta: Gramedia Pustaka Utama, 1997)

Rivers, Wilga M. 1981. Teaching Foreign Language Skills. Second Edition. Chicago and London: The University of Chicago Press.

Rubin, Dorothy. 1982. A Practical Approach to Teaching Reading. New York: Holt, Rinehart and Winston.

Schmitt, Norbert. 2000. Vocabulary in Language Teaching. Cambridge: Cambridge University Press.

Sevilla, Consuelo G, dkk. 2006. Pengantar Metode Penelitian. Jakarta: Universitas Indonesia.

Sudjana. 2003.Metode Statistika. Bandung: AlfaBeta.

Sugiyono. 2008.Metode Penelitian Pendidikan: Pendekatan Kuantitatif, Kualitatif, dan R\&D. Bandung: Alfabeta. 
Thornbury, Scott. 2002. How to Teach Vocabulary. Longman. Pearson Education Limited. Usman, Husaini dan Akbar, Setiady R Purnomo. 2006. Pengantar Statistika. Edisi Kedua. Jakarta: Bumi Aksara.

Zintz, Miles V. 1972. The Reading Process: The Teacher and The Learner.

University of New Mexico: WM. C. Brown Company Publishers.

http://en.wikipedia.org/wiki/habit

http://hubpages.com/slide/developing-a-reading-habit 